\title{
Vermicompost leachate as a supplement to increase tomato fruit quality
}

\author{
L. Ávila-Juárez ${ }^{1 *}$, A. Rodríguez González ${ }^{1}$, N. Rodríguez Piña ${ }^{2}$, R.G. Guevara \\ González $^{1 *}$, I. Torres Pacheco ${ }^{1}$, R.V. Ocampo Velázquez ${ }^{1}$, Bah Moustapha $^{3}$
}

${ }^{1}$ Biosystems Laboratory. Universidad Autónoma de Querétaro, C.P. 76010. Querétaro, México. ${ }^{2}$ Facultad de Lenguas y Letras. Universidad Autónoma de Querétaro. CP.76850. Querétaro, México. ${ }^{3}$ Division of Natural Products Research, Faculty of Chemistry, Universidad Autónoma de Querétaro,. C.P. 76010. Querétaro, México.*Corresponding authors: lucianoavila.j@hotmail.com

\begin{abstract}
Due to low yields, organic agriculture cannot satisfy the global demand for food, although it can provide products of higher nutraceutical quality. The objective of this research was to incorporate vermicompost leachates (VCLs) into an irrigation system during tomato (Solanum lycopersicum cv. Rafaello) cultivation to evaluate their effects on the lycopene, $\beta$-carotene, and phenolic content of tomatoes and on the physical and chemical soil variables. To evaluate the effects of VCLs, three types of substrates were used to create VCLs: mushroom waste (MSHW), leaf-cutting ant waste (LCAW), and cow compost (CC). A total of $0.1 \mathrm{~L}$ of leachate per plant was added as a supplement to a nutrient solution (NS) and applied once weekly, twice weekly, or every fifteen days to three different treatments for each leachate. All VCLs had a positive effect on the production of lycopene; the best results were obtained by the application of the MSHW (78 $\mathrm{mg} \mathrm{kg}^{-1}$ fresh weight). The VCL decreased the presence of ions phytotoxic to plants by $99 \%$ and improved the soil structure by increasing the amount of organic matter and the hydraulic conductivity. However, the VCL had no effect on the physiological variables. The results support the use of leachate from $\mathrm{CC}$ via fertigation twice a week at a dose of $0.1 \mathrm{~L} \mathrm{plant}^{-1}$ because it increases lycopene content by $67 \%$.
\end{abstract}

Keywords: Organic agriculture, conventional agriculture, vermicompost leachate, lycopene, $\beta$-carotene, fruit quality 


\section{Introduction}

There is a consensus that organic agriculture (OA) cannot meet the global demand for vegetables because only $0.3 \%$ of the land used for agriculture is used for OA (Connor, 2008), and in some crops, yields are only $30 \%$ of those obtained from conventional agriculture (CA) (de Ponti et al., 2012). Low organic crop (OC) yields are due to the permanent stress caused by an ionic imbalance resulting from crop nutrition practices (usually organic amendments). In contrast, CA, heavy doses of chemical fertilizers and pesticides are often used to improve the yield of various horticultural crops (Márquez-Quiroz et al., 2014). Both types of chemicals create a state of "comfort" for the plant (Bennett et al., 2012) that generates high fruit yields but low nutraceutical quality. Therefore, a third approach to agriculture is integrated crop management (ICM), i.e., a method that blends conventional and organic agriculture and is intended to support agricultural production, maintain revenues, protect the environment, and respond to the consumer demand for food with nutraceutical qualities.

The use of vermicompost (VC) is considered a technique capable of increasing the nutritional value of fruits such as tomatoes (Gutiérrez-Miceli et al., 2007). For example, this technique has increased the levels of vitamin C, phenolic compounds, carotenoids (lycopene and $\beta$-carotene), and antioxidant activity (AA) (Huber et al., 2011). In the production of $\mathrm{VC}$, leachates, which are excreted by microorganisms, must be collected to avoid saturation of the production unit. These leachates are considered to be beneficial to the plant because they can be used as fertilizers because of their high humic acid and nutrient contents (Tejada et al., 2008). These acids regulate many processes in crop development, help retain soil humidity, and are capable of chelating certain metal ions, which reduces leaching.
Currently, consumers generally focus on functional foods that both nourish and provide health benefits. Tomatoes are the most important source of lycopene in the human diet (Vitale et al., 2010). Epidemiological studies report that regular consumption of lycopene decreases the risk of prostate cancer and cardiovascular disease (Story et al., 2010). Accordingly, VC can be used to increase the nutraceutical quality of tomatoes, but it should be noted that the effect of VC depends on various factors, such as the crop on which the system is built, the physico-chemical and biological properties of the $\mathrm{VC}$, and the target crop species. For example, when using VC in long-cycle crops, such as indeterminate tomatoes, fruit yield may be affected and yield only approximately $192 \mathrm{t} \mathrm{ha}^{-1}$ in a greenhouse (Goswami et al., 2001), whereas chemical fertilizers in CA can produce up to $400 \mathrm{t} \mathrm{ha}^{-1}$ (Resh, 2001).

Some studies report that using VC as a unique source of nutrition may diminish fruit yield or even cause the death of the plant (Lazcano and Domínguez, 2010). Today, agricultural practices primarily focus on the production of high fruit yields of standard quality. However, it is difficult to find a balance between yield and quality because the latter usually requires some type of stress in the crops (Frost et al., 2008), which causes decreased fruit production. The aim of this work was to incorporate vermicompost leachates (VCLs) into a greenhouse tomato crop to improve the nutraceutical quality of the fruit without compromising yield.

\section{Methodology}

The experiment was conducted at the Universidad Autónoma de Querétaro, Campus Amealco, 
Querétaro, México (20 $11^{\prime} 17^{\prime}$ ' latitude north and $100^{\circ} 08^{\prime} 38^{\prime \prime}$ longitude west) during 2013.

\subsection{Vermicompost substrates (VCS) and VCL production}

For the production of VCL, the following VCSs were used: a) cow compost (CC), obtained from freegrazing cows; b) mushroom waste (MSHW), based on barley stubble, corn, and organic peat; and c) leaf-cutting ant waste (LCAW), obtained from Atta mexicana $\mathrm{S}$. and only collected from organic material that was removed from ant nests in the area. For VCL production, beds of cement blocks were built $(1 \mathrm{~m}$ wide by $10 \mathrm{~m}$ long and $0.5 \mathrm{~m}$ high) with a slope of $1 \%$. A total of 5000 earthworms (Eisenia fetida) were inoculated per $\mathrm{m}^{2}$ and fed $10 \mathrm{~kg} \mathrm{~m}^{-2}$ VCS every 15 days. Humidity was maintained at $60-90 \%$, and the average temperature was $19^{\circ} \mathrm{C}$. The VC process was maintained for 6 months, and during that time, VCLs were collected and stored in black containers.

\section{Chemical and physical characterization of VCS and $V C L$}

Before starting the VC process, the VCSs were analyzed, as were the VCLs once they were obtained. Both were sent to a certified laboratory (Laboratorio de Nutrición Vegetal S.C. Guanajuato, México) to analyze $\mathrm{pH}$, total nitrogen $(\mathrm{N})$, phosphorus $\left(\mathrm{P}_{2} \mathrm{O}_{5}\right)$, potassium $\left(\mathrm{K}_{2} \mathrm{O}\right)$, calcium $(\mathrm{Ca})$, magnesium $(\mathrm{Mg})$, iron $(\mathrm{Fe})$, copper $(\mathrm{Cu})$, manganese $(\mathrm{Mn})$, zinc $(\mathrm{Zn})$, sodium $(\mathrm{Na})$, sulfur $(\mathrm{S})$, boron $(\mathrm{B})$, organic material $(\mathrm{OM})$, ash, organic carbon, $\mathrm{C} / \mathrm{N}$ ratio, electrical conductivity (EC), and humidity. $\mathrm{N}$ was measured according to the Kjeldahal method. $\mathrm{EC}$ and $\mathrm{pH}$ were determined following the Norma Mexicana NMX-FF109-SCFI-2007. $\mathrm{K}_{2} \mathrm{O}, \mathrm{Ca}, \mathrm{Mg}, \mathrm{Na}, \mathrm{Fe}, \mathrm{Cu}, \mathrm{Mn}$, and $\mathrm{Zn}$ were analyzed by atomic absorption following wet digestion of the material. $\mathrm{P}_{2} \mathrm{O}_{5}$ and $\mathrm{B}$ were determined by spectrophotometry after digestion and calcination, respectively. Humidity was evaluated through the gravimetric method. Ash and organic materials were measured after calcination. Organic carbon was calculated as a $\%$ of the material, whereas the $\mathrm{C} / \mathrm{N}$ ratio was determined based on the dry material.

\subsection{Experimental design}

The experiment was conducted in an elliptical greenhouse (temperatures of 10 to $27^{\circ} \mathrm{C}$ and a relative humidity of 45 to $90 \%$ ) with natural ventilation that was covered with plastic measuring 180 microns thick. Tomato was cultivated at a density of 2.5 plants $\mathrm{m}^{-2}$ after transplantation to soil (soil characteristics shown in Table 2 as "Soil before").

The experimental design consisted of randomized complete blocks and 10 treatments (including control) with three replicates each. The experimental unit contained 3 plants. Each furrow had a block for each treatment. A total of three furrows were used to complete the three replicates. The block size was four meters long, and each block had 23 plants, of which three center plants were selected for the sample. Variables included VCL type and time of application: 1W, 2W, EFD. The treatments (T) were T1: MSHW 1W, T2: MSHW 2W, T3: MSHW EFD, T4: LCAW 1W, T5: LCAW 2W, T6: LCAW EFD, T7: CC 1W, T8: CC 2W, T9: CC EFD, and T10 (control): SCHF chemical fertilization only (Steiner, 1984). Leachates were used to supplement the NS in all treatments (except the control) and were applied through the irrigation system from 30 days after transplantation (DAT) until the end of cultivation. The amount of leachate applied was $0.1 \mathrm{~L}_{\text {plant }}{ }^{-1}$ at $2.5 \mathrm{dS} \mathrm{m}^{-1} \mathrm{EC}$ and a $\mathrm{pH}$ of 5.8. The chemical nutrition of the plants was divided into NS stages based on Steiner (1984) as follows: an EC of $1.5 \mathrm{dS} \mathrm{m}^{-1}$ from the time of transplantation until the third cluster was tied, an EC of $2 \mathrm{dS} \mathrm{m}^{-1}$ from the third cluster 
to the sixth cluster, and an EC of $2 \mathrm{dS} \mathrm{m}^{-1}$ from the sixth cluster until the end of the cycle.

\subsection{Variables evaluated}

Crop variables

The following plant variables were measured weekly: plant height (PLH), leaf length (LL), number of fruits per plant (NFP), stem diameter (SD), fruit equatorial diameter (EDF), fruit polar diameter (PDF), fresh fruit weight (FFW), number of fruits per plant (NFP), and fruit yield $(\mathrm{kg})$ per plant.

Soil chemical and physical variables

Soil variables were measured before and at the end of the experiments. The samples were obtained at a depth of $30 \mathrm{~cm}$ in each treatment and analyzed by a certified laboratory (Laboratorio de Nutrición Vegetal, S.C. Guanajuato, México). The following physical properties were examined: saturation (SAT), field capacity (FC), wilting point (WP), hydraulic conductivity (HC), bulk density (BD), cation exchange capacity (CEC) and EC. The chemical properties determined included $\mathrm{OM}$, inorganic nitrogen (IN), total $\mathrm{P}, \mathrm{K}, \mathrm{Ca}, \mathrm{Mg}, \mathrm{Na}, \mathrm{Fe}, \mathrm{Zn}, \mathrm{Mn}, \mathrm{Cu}, \mathrm{B}, \mathrm{S}$, and $\mathrm{pH}$. IN was measured according to the Kjeldahal method. EC and $\mathrm{pH}$ were determined following the Norma Mexicana NMX-FF-109-SCFI-2007. K, Ca, $\mathrm{Mg}, \mathrm{Na}, \mathrm{Fe}, \mathrm{Cu}, \mathrm{Mn}$, and $\mathrm{Zn}$ were analyzed by atomic absorption after wet digestion of the material. $\mathrm{P}$ and $\mathrm{B}$ were determined by spectrophotometry after digestion and calcination, respectively.

Tomato fruit variables

The tomatoes were harvested when their color turned red. In each treatment, ${ }^{\circ}$ Brix, EC, and $\mathrm{pH}$ were measured in a randomly selected fruit. Additionally, a preliminary chemical study was conducted to determine the yield tendency for $\beta$-carotene, lycopene, and phenolics in T2, T5, T8, and T10 as a result of the effects of applying VCL twice a week. The measurement of ${ }^{\circ}$ Brix was made from juice extracted from freshly harvested fruit using a digital refractometer (Model HI 96801 Hanna Inc., USA) and expressed as the percentage of sugar.

\subsection{HPLC determination of lycopene, $\beta$-carotene, and rutin}

Instrumentation

The HPLC analysis was conducted on a Waters apparatus (Millipore Corp., Waters Chromatography Division, Milford, MA) composed of a 600E multisolvent delivery system equipped with a photodiode array detector (2998 Waters) and an electronic degasser (MetaChem Technologies, Inc.). Control of the equipment, data acquisition, processing, and management of the chromatographic information were performed with the Empower3 software (Waters).

Sample preparation for analysis

Freshly harvested tomato fruits from cluster number 7 were stored at $-20{ }^{\circ} \mathrm{C}$ for two days. The fruits were then homogenized in a blender (Ultra turax) for $1 \mathrm{~min}$ and protected from light with aluminum foil.

For the extraction of carotenoids, $1 \mathrm{ml}$ of $2.5 \%$ butyl hydroxytoluene (BHT) (0.25 g BHT in $10 \mathrm{ml}$ ethanol) was added to $50 \mathrm{ml}$ of the homogenate (approximately $40 \mathrm{~g}$ ). The mixture was shaken for $10 \mathrm{~min}$. Then, 20 $\mathrm{ml}$ of hexane:acetone:ethanol (2:1:1, v:v:v) (adapted from Toora et al., 2006) was added, and the mixture was shaken again for $5 \mathrm{~min}$ and filtered through a glass Büchner funnel with a porous disc (10 to $15 \mu \mathrm{m})$. Two 
additional extractions were performed, and $3 \mathrm{ml}$ of $40 \%$ methanolic $\mathrm{NaOH}$ ( $8 \mathrm{~g} \mathrm{NaOH}$ in $20 \mathrm{ml}$ methanol) was added to the total extract. The mixture was heated at $56^{\circ} \mathrm{C}$ for $20 \mathrm{~min}$ and immediately cooled in a water bath at room temperature. A total of $10 \mathrm{ml}$ of hexane was added, and the mixture was shaken for $1 \mathrm{~min}$. To this solution, $50 \mathrm{ml}$ of $10 \% \mathrm{NaCl}(20 \mathrm{~g} \mathrm{NaCl}$ in 180 $\mathrm{ml} \mathrm{H}_{2} \mathrm{O}$ ) was added, and the mixture was shaken for $1 \mathrm{~min}$ and left untouched to allow the two layers to separate from each other. The upper layer (hexane) was collected, dried over anhydrous sodium sulfate, filtered, and evaporated until dry, and the residue was analyzed to identify the carotenoids.

For phenolic extraction, a mixture of $50 \mathrm{ml} \mathrm{MeOH}$ and $50 \mathrm{ml}$ of the homogenized tomato was stirred for $5 \mathrm{~min}$, filtered and evaporated under reduced pressure until dry. The residue was re-dissolved in $5 \mathrm{ml} \mathrm{H}_{2} \mathrm{O}$ (HPLC grade), and $1 \mathrm{ml}$ of this solution was filtered across regenerated cellulose acrodiscs (Econofilter with a $25 \mathrm{~mm}$ diameter and a $0.2 \mu \mathrm{m}$ pore size, Agilent Technologies), and the residue was analyzed to identify the phenolics. The remaining 4 $\mathrm{ml}$ was divided into two equal portions for acid and base hydrolyses. Each portion was stirred for $2 \mathrm{~h}$ with $2 \mathrm{~N} \mathrm{HCl}$ (or $2 \mathrm{~N} \mathrm{NaOH}$ ) in an $80^{\circ} \mathrm{C}$ water bath. These processes were conducted in only two samples (T1 and $\mathrm{T} 2$ ).

\section{HPLC analysis}

\section{Analysis of carotenoids}

For the analysis of carotenoids, a YMC reversed-phase carotenoid column (Merck) (C30; 150 x 4.6 mm i.d.; S-3 $\mu \mathrm{m}$ ) was used. A binary linear gradient system composed of A) methanol/methyl-t-butyl-ether (MTBE)/ $\mathrm{H}_{2} \mathrm{O}$ (81:15:4) and B) methanol/MTBE/ $\mathrm{H}_{2} \mathrm{O}$ (6:90:4) was used. The elution mode was set

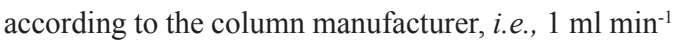

from 0 to $100 \%$ B (0-90 min) followed by column re-equilibration for $10 \mathrm{~min}$. Detection was performed at $450 \mathrm{~nm}$. To prepare the sample for injection, the total dried hexane extract was re-dissolved in $10 \mathrm{ml}$ of a mixture of $\mathrm{CH}_{2} \mathrm{Cl}_{2}$ and the mobile phase $\mathrm{B}(1: 1)$. Aliquots of this dissolution were filtered through acrodiscs, and $20 \mu \mathrm{l}$ was injected into a Rheodyne (7725i) with a $20 \mu 1$ loop. Compound identification was performed through a comparison of the retention times and $\lambda_{\text {max }}$ of the peaks in the sample with those of pure commercial lycopene and $\beta$-carotene (SigmaAldrich). Quantification of the compounds was achieved using a calibration curve obtained from $\beta$-carotene at the concentrations of $0.05,0.1,0.2$, and $0.4 \mu \mathrm{g} \beta$-carotene in $20 \mu \mathrm{l}$ of $\mathrm{CH}_{2} \mathrm{Cl}_{2}$ and mobile phase $\mathrm{B}(1: 1)$. The results were expressed as $\mathrm{mg} \mathrm{kg}^{-1}$ of fresh fruit.

Analysis of phenolics

The following phenolic standards were used: chlorogenic, caffeic, ferulic, and protocatechuic acids and the flavonoids (-)-epicatechin, $(+)$-catechin, kaempferol, rutin, and quercetin (all from Sigma-Aldrich). Analyses were conducted according to a method routinely used in our laboratory involving the ZORBAX Eclipse XDB-C18 column $(3.5 \mu \mathrm{m}, 150 \times 4.6 \mathrm{~mm}$ i.d. $)$ provided with a pre-column (Agilent). The mobile phase consisted of a binary gradient composed of A) $\mathrm{CH}_{3} \mathrm{CN}$ and B) AcOH $0.0125 \mathrm{~N}$. The elution mode was as follows: $95 \% \mathrm{AcOH} 0.0125 \mathrm{~N}$ from 0 to 2.0 $\mathrm{min}, 95 \%$ to $85 \%$ from 2.0 to $5.0 \mathrm{~min}, 85 \%$ to $50 \%$ from $5.0 \mathrm{~min}$ to $20 \mathrm{~min}$, and $50 \%$ to $95 \%$ from 20 $\min$ to $25 \mathrm{~min}$. The column was equilibrated with this final composition until $35 \mathrm{~min}$ had passed. The flow rate was $0.8 \mathrm{ml} \mathrm{min}$, detection was performed at $280 \mathrm{~nm}$, the injection volume was $20 \mu \mathrm{l}$, and the total elution time was $40 \mathrm{~min}$. 


\subsection{Statistical Analysis}

A one-way analysis of variance (ANOVA) was conducted for all parameters except for lycopene, $\beta$-carotene, and rutin. Differences between treatments were determined by Tukey>s test using Origin Pro 8.0 software (OriginLab®). Significance was defined as $p \leq 0.05$.

\section{Results}

\subsection{Chemical and physical characterization of VCSs and VCLs}

The macroelement contents (total $\mathrm{N}, \mathrm{P}_{2} \mathrm{O}_{5}, \mathrm{Ca}$, and $\mathrm{Mg}$ ) in all VCLs were similar except for the $\mathrm{K}$ content. The $\mathrm{N}$ content was reduced (most likely volatilized) from VCSs to VCLs by up to $97.7 \%, 97.8 \%$, and $97.3 \%$ in MSHW, LCAW, and CC, respectively; the same tendency was observed for $\mathrm{P}\left(\mathrm{P}_{2} \mathrm{O}_{5}\right)$. In contrast, the total macroelements $(\mathrm{K}, \mathrm{Ca}, \mathrm{Mg}$, and $\mathrm{Na}$ ) were reduced in all treatments; the greatest reduction was observed in MSHW (68.7\%), and the lowest reduction was observed in CC (48\%). The same tendency was observed with the total microelements $(\mathrm{Fe}, \mathrm{Cu}, \mathrm{Zn}$, and $\mathrm{Mn}$ ) from the input (VCS) to the output (VCL), which reached up to 99\% in the CC. Among all of the treatments analyzed, LCAW had the highest content of Fe $(0.004 \%)$ (Table 1$)$. Regarding the physical properties, the $\mathrm{EC}$ was reduced in all of the treatments except CC.

\subsection{Effect of VCL on soil properties}

The soil physical properties differed due to the application of VCL. For example, the VCLs modified the soil structure, which was reflected in a higher SAT and FC. In addition, a difference was observed in HC between the untreated and treated soils. The effect was most prominent with the SCHF treatment (87.8\%), followed by CC $(76.8 \%)$. Furthermore, the application of VCL via irrigation produced an accumulation of metals, such as microelements, which are known to be antagonistic. In fact, compared with the initial soil conditions, the results showed an accumulation of $\mathrm{Na}+$ in the soil treated with VCL and the control (SCHF), which had the greatest accumulation (Table 2).

Table 1. Chemical and physical characterization of VC substrates and VCL.

\begin{tabular}{|c|c|c|c|c|c|c|}
\hline & \multicolumn{3}{|c|}{ Substrates (VC) } & \multicolumn{3}{|c|}{ Leachate (VCL) } \\
\hline Element & MSHW & LCAW & $\mathrm{CC}$ & MSHW & LCAW & $\mathrm{CC}$ \\
\hline $\mathrm{pH}$ & 6.98 & 6.34 & 7.26 & 9.06 & 7.66 & 7.27 \\
\hline $\mathrm{EC}\left(\mathrm{dS} \mathrm{m^{-1 } )}\right.$ & 7.9 & 6.3 & 3.5 & 4.6 & 5.30 & 6.60 \\
\hline $\mathrm{N}$ total $(\%)$ & 1.8 & 1.9 & 1.49 & 0.04 & 0.04 & 0.04 \\
\hline $\mathrm{P}\left(\mathrm{P}_{2} \mathrm{O}_{5}\right)(\%)$ & 0.57 & 0.11 & 0.63 & 0.01 & 0.01 & 0.01 \\
\hline $\mathrm{K}(\mathrm{K}, \mathrm{O})(\%)$ & 1.93 & 1.56 & 0.89 & 1.08 & 1 & 0.94 \\
\hline $\mathrm{Ca}(\%)$ & 2.03 & 0.89 & 0.96 & 0.04 & 0.04 & 0.04 \\
\hline $\operatorname{Mg}(\%)$ & 0.3 & 0.22 & 0.30 & 0.02 & 0.02 & 0.02 \\
\hline $\mathrm{Na}(\%)$ & 0.77 & 0.95 & 0.62 & 0.43 & 0.37 & 0.44 \\
\hline $\mathrm{S}(\%)$ & 1.32 & 0.22 & 0.34 & 0.03 & 0.03 & 0.05 \\
\hline $\mathrm{Fe}(\%)$ & 0.72 & 0.92 & 0.85 & 0.001 & 0.004 & 0.001 \\
\hline $\mathrm{Cu}(\mathrm{ppm})$ & 39.2 & 17.6 & 41.3 & 4.48 & 5.89 & 6.27 \\
\hline $\mathrm{Mn}(\mathrm{ppm})$ & 592 & 533 & 855 & 3.05 & 2.50 & 1.71 \\
\hline $\mathrm{Zn}(\mathrm{ppm})$ & 277 & 57.2 & 334 & 10.5 & 2.47 & 3.99 \\
\hline $\mathrm{B}(\mathrm{ppm})$ & 23.3 & 22.9 & 18.8 & 0.01 & 0.01 & 0.01 \\
\hline Humidity (\%) & 59.8 & 11.4 & 59.4 & 99.3 & 99.4 & 99.4 \\
\hline $\mathrm{OM}(\%)$ & 47.7 & 47.3 & 51.3 & 44.9 & 58.5 & 37.1 \\
\hline $\operatorname{Ash}(\%)$ & 52.3 & 52.7 & 48.7 & 55.1 & 41.5 & 62.9 \\
\hline Organic C. $(\%)$ & 27.7 & 27.4 & 29.8 & 26 & 34 & 21.5 \\
\hline Ratio C/N & 15.3 & 14.4 & 20 & 650 & 850 & 537.5 \\
\hline
\end{tabular}


Table 2. Soil analysis before and after the experiment with VCL.

\begin{tabular}{|l|c|c|c|c|c|}
\hline & \multirow{2}{*}{ Soil before } & \multicolumn{4}{|c|}{ Soil after } \\
\hline & & MSHW & LCAW & CC & SCHF \\
\hline Physical properties & & & & & \\
\hline SAT (\%) & 53.95 & 55.55 & 55.75 & 60.75 & 59.15 \\
\hline FC (\%) & 28.85 & 29.65 & 29.85 & 32.55 & 31.65 \\
\hline WP (\%) & 17.15 & 17.65 & 17.75 & 19.35 & 18.85 \\
\hline HC (cm hr $\left.{ }^{-1}\right)$ & 4.10 & 2.25 & 2.25 & 0.95 & 0.50 \\
\hline BD (g cm $\left.{ }^{-3}\right)$ & 1.00 & 0.85 & 0.92 & 0.87 & 0.86 \\
\hline EC (dS m $\left.{ }^{-1}\right)$ & 0.06 & 8.12 & 7.38 & 2.17 & 12.05 \\
\hline CEC (meq 100 g-1) & 11.05 & 36.95 & 34.05 & 30.95 & 46.65 \\
\hline Chemical properties & & & & & \\
\hline OM (\%) & 1.24 & 3.73 & 3.19 & 4.14 & 3.6 \\
\hline pH (1:2 water) & 6.66 & 6.85 & 6.45 & 6.75 & 6.35 \\
\hline IN (ppm) & 3.46 & 10.15 & 9.43 & 12.85 & 9.43 \\
\hline P-Bray (ppm) & 0.61 & 82.95 & 111 & 69.75 & 68.05 \\
\hline K (ppm) & 173 & 1424 & 1962 & 2461 & 1968 \\
\hline Ca (ppm) & 1557 & 5054 & 4331 & 4751 & 6346 \\
\hline Mg (ppm) & 340 & 810 & 731 & 924 & 897 \\
\hline Na (ppm) & 14.95 & 324 & 309 & 349 & 562 \\
\hline Fe (ppm) & 7.29 & 22.05 & 23.45 & 21.95 & 22.05 \\
\hline Zn (ppm) & 0.34 & 14.35 & 11.25 & 21.45 & 16.35 \\
\hline Mn (ppm) & 20.75 & 18.55 & 21.85 & 31.45 & 24.85 \\
\hline Cu (ppm) & 0.18 & 2.69 & 0.87 & 1.38 & 2.62 \\
\hline B (ppm) & 0.05 & 0.49 & 0.42 & 1.39 & 0.57 \\
\hline S (ppm) & 6.05 & 1536 & 1502 & 1171 & 3047 \\
\hline & & & & & \\
\hline & & & & \\
\hline
\end{tabular}

${ }^{1}$ The samples, except for the control, were collected from each VCL treatment and were mixed and then analyzed. For example, T1, T2, and T3 were used in the case of MSHW. The sample was obtained at a $30 \mathrm{~cm}$ depth.

\subsection{Crop physiological variables}

Fresh fruit weights (FFW) did not differ among the treatments $(p \leq 0.05)$; the same trend was observed for all physiological variables. Thus, the VCL did not affect the crop physiological variables.

The VCL caused no significant differences $(p \leq 0.05)$ in tomato yield between the treatments; it appears that the VCL only generated changes in the soil structure and chemical properties. During the course of the experiment, the VCL generally failed to produce changes in the physiological variables of the tomato plant. Thus, fruit yield seemed to depend on both the type and the frequency of the treatments applied (Figure 1). 


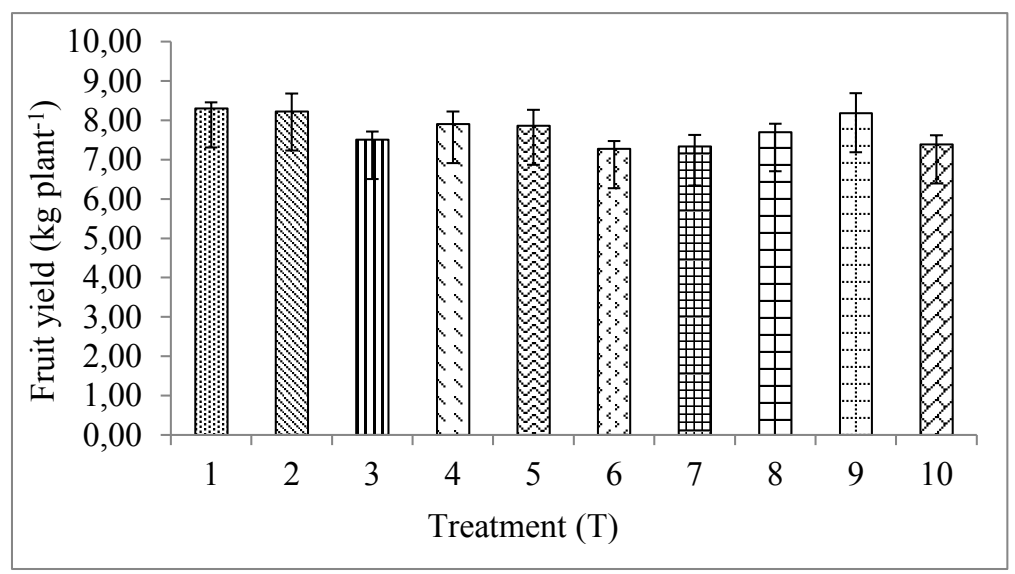

Figure 1. Average yield of tomato fruit after VCL application.

Yield of tomato fruit (mean \pm standard error) $(n=6)$. Columns followed by the same letter are not significantly different at $\mathrm{P} \leq 0.05$.

\subsection{Tomato fruit variables}

No significant differences $(p \leq 0.05)$ were observed between the treatments in terms of sugar content in the tomato fruit because all treatments achieved ${ }^{\circ}$ Brix values between 5.14 and 5.35. The treatment values were all slightly higher than that of the control (T10), which produced a value of 5.15. In contrast, similar results were observed for all the $\mathrm{pH}$ values (between 5.9 and 6.08), including that of the control (T10). Likewise, the EC of the fruit ranged from 4.08 to 4.6 , including for the control. Thus, no significant effect was observed for these variables as a consequence of VCL application (Table 4).

Table 3. Physiological variables in tomato plants as a function of the effects of VCL.

\begin{tabular}{|c|c|c|c|c|c|c|c|}
\hline Treatment $(\mathrm{T})$ & PLH $(\mathrm{cm})$ & SD $(\mathrm{mm})$ & LL $(\mathrm{cm})$ & PDF $(\mathrm{mm})$ & EDF $(\mathrm{mm})$ & FFW $(\mathrm{g})$ & NFP \\
\hline 1 & $19.56 \pm 0.38$ & $6.87 \pm 0.22$ & $28.10 \pm 0.92$ & $79.23 \pm 1.32$ & $57.60 \pm 0.44$ & $157.47 \pm 1.46$ & $53 \pm 0.78$ \\
\hline 2 & $18.97 \pm 0.30$ & $6.74 \pm 0.10$ & $28.42 \pm 0.45$ & $79.58 \pm 1.39$ & $57.19 \pm 1.05$ & $154.51 \pm 7.26$ & $53 \pm 0.61$ \\
\hline 3 & $19.20 \pm 0.27$ & $6.75 \pm 0.12$ & $27.77 \pm 0.62$ & $76.95 \pm 1.31$ & $56.53 \pm 0.47$ & $143.71 \pm 3.03$ & $52 \pm 0.67$ \\
\hline 4 & $19.77 \pm 0.46$ & $7.12 \pm 0.25$ & $29.14 \pm 0.98$ & $78.37 \pm 1.81$ & $56.55 \pm 0.64$ & $145.90 \pm 5.88$ & $54 \pm 0.48$ \\
\hline 5 & $19.36 \pm 0.29$ & $6.47 \pm 0.23$ & $27.51 \pm 0.88$ & $80.41 \pm 1.30$ & $57.19 \pm 0.97$ & $149.70 \pm 6.35$ & $52 \pm 1.04$ \\
\hline 6 & $18.94 \pm 0.59$ & $6.64 \pm 0.18$ & $27.28 \pm 0.72$ & $77.72 \pm 1.23$ & $55.48 \pm 0.69$ & $137.27 \pm 5.07$ & $53 \pm 0.85$ \\
\hline 7 & $19.27 \pm 0.20$ & $6.66 \pm 0.15$ & $27.83 \pm 0.81$ & $77.41 \pm 1.16$ & $55.10 \pm 0.76$ & $136.07 \pm 4.85$ & $54 \pm 0.40$ \\
\hline 8 & $19.37 \pm 0.33$ & $6.91 \pm 0.15$ & $29.07 \pm 0.22$ & $79.36 \pm 0.77$ & $56.05 \pm 0.45$ & $144.54 \pm 4.10$ & $53 \pm 0.80$ \\
\hline 9 & $18.95 \pm 0.41$ & $6.65 \pm 0.27$ & $28.37 \pm 0.75$ & $81.14 \pm 1.40$ & $57.35 \pm 1.43$ & $150.48 \pm 4.90$ & $54 \pm 1.85$ \\
\hline 10 & $18.90 \pm 0.21$ & $6.49 \pm 0.10$ & $28.12 \pm 0.49$ & $78.97 \pm 1.50$ & $55.80 \pm 1.15$ & $146.62 \pm 3.51$ & $50 \pm 0.77$ \\
\hline & NS & NS & NS & NS & NS & NS & NS \\
\hline
\end{tabular}

Values represent the mean \pm standard error of the mean $(n=6)$. NS $=$ non-significant, $P \leq 0.05$. 
Table 4. Tomato fruit variables according to different VCL treatments.

\begin{tabular}{|c|c|c|c|}
\hline Treatment $(\mathrm{T})$ & $\mathrm{pH}$ & $\mathrm{EC}\left(\mathrm{dS} \mathrm{m}^{-1}\right)$ & ${ }^{\circ}$ Brix $(\%$ sugar $)$ \\
\hline 1 & $6.00 \pm 0.09$ & $4.28 \pm 0.16$ & $5.19 \pm 0.10$ \\
\hline 2 & $6.08 \pm 0.07$ & $4.08 \pm 0.12$ & $5.14 \pm 0.11$ \\
\hline 3 & $5.99 \pm 0.04$ & $4.37 \pm 0.46$ & $5.21 \pm 0.13$ \\
\hline 4 & $5.95 \pm 0.05$ & $4.38 \pm 0.45$ & $5.15 \pm 0.09$ \\
\hline 5 & $6.05 \pm 0.09$ & $4.34 \pm 0.39$ & $5.23 \pm 0.14$ \\
\hline 6 & $5.99 \pm 0.06$ & $4.57 \pm 0.41$ & $5.35 \pm 0.14$ \\
\hline 7 & $5.94 \pm 0.03$ & $4.56 \pm 0.31$ & $5.18 \pm 0.11$ \\
\hline 8 & $5.90 \pm 0.05$ & $4.60 \pm 0.22$ & $5.22 \pm 0.03$ \\
\hline 9 & $5.93 \pm 0.06$ & $4.33 \pm 0.40$ & $5.28 \pm 0.13$ \\
\hline 10 & $5.99 \pm 0.04$ & $4.40 \pm 0.27$ & $5.15 \pm 0.08$ \\
\hline & $\mathrm{NS}$ & $\mathrm{NS}$ & $\mathrm{NS}$ \\
\hline
\end{tabular}

Values represent the mean \pm standard error of the mean $(n=3)$. NS $=$ non-significant, $P \leq 0.05$.

\subsection{Identification and quantification of lycopene,} $\beta$-carotene, and rutin

An HPLC analysis of the extracts generated essentially the same profile as that shown for T5 in Figure 2. The two major carotenoids matched the characteristics of pure $\beta$-carotene and lycopene (Rt $\approx 29 \mathrm{~min}$ and $61 \mathrm{~min}$, respectively, and $\lambda_{\text {max }}$ in their respective UV spectra, as shown in Figure 3). Thus, it is plausible that the other treatments might have similar carotenoid profiles. Chromatograms and UV spectra of the other three samples can be found in the Supplementary Information. With regard to the phenolics that were investigated, only rutin was detected, but in low quantities $\left(0.13 \mathrm{mg} \mathrm{kg}^{-1}\right.$ fresh fruit on average).

Quantification of the compounds (lycopene, $\beta$-carotene, and rutin) by extrapolation to the fresh fruit yielded the quantities shown in Table 5.

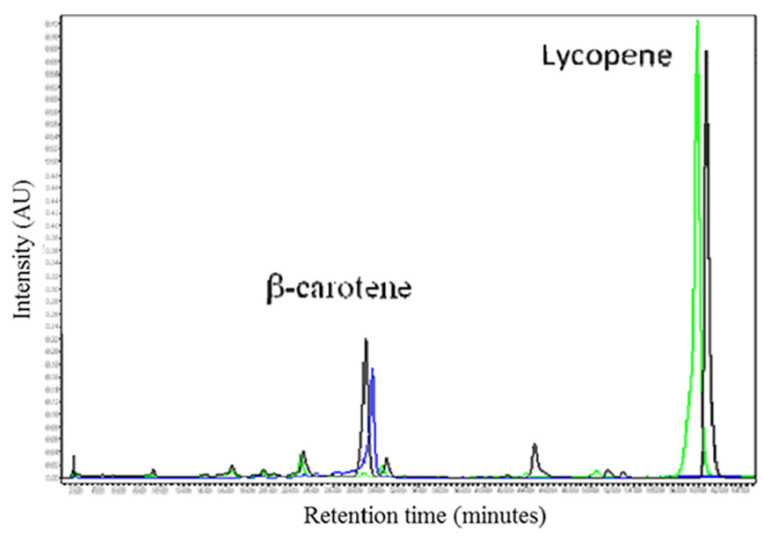

Figure 2. Comparative HPLC chromatograms of T5 (black), pure lycopene (green), and $\beta$-carotene (blue). 

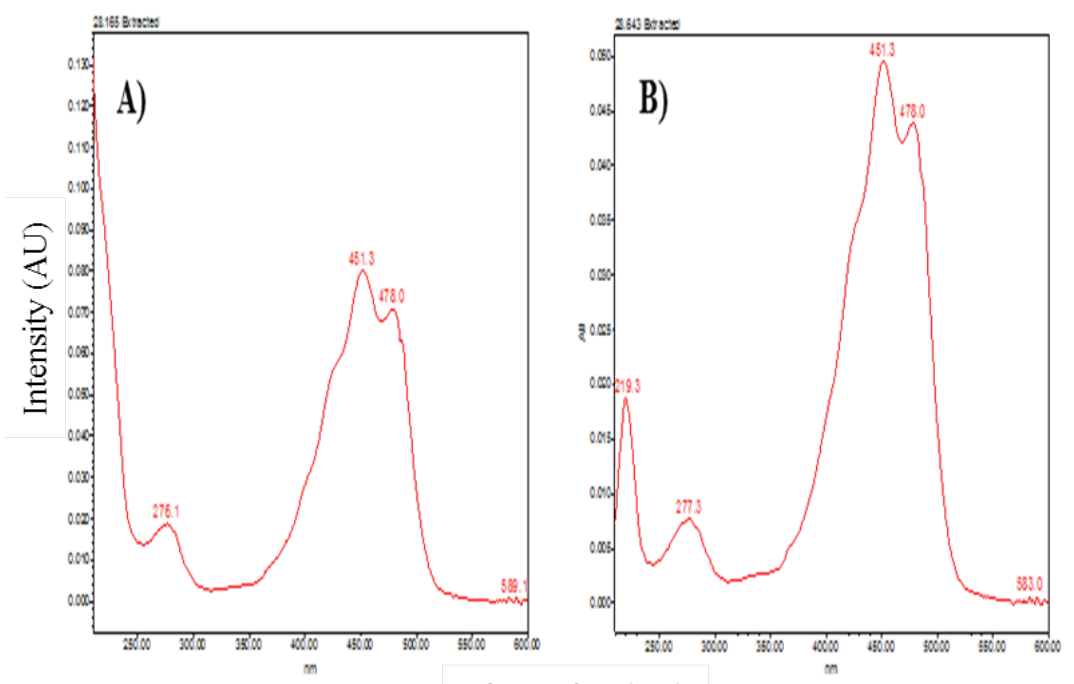

Absorption (nm)

Figure 3. UV spectra of the peak at $28.16 \mathrm{~min}$ of sample T5 (A) and $\beta$-carotene (B).

Table 5. Yields of the two carotenoids and rutin found in the extracts from the different treatments.

\begin{tabular}{|c|c|c|c|}
\hline \multirow[b]{2}{*}{ Treatment $(\mathrm{T})$} & \multicolumn{3}{|c|}{ Yield (mg kg-1 fresh fruit) (extrapolated) } \\
\hline & $\beta$-carotene & lycopene & rutin \\
\hline 2 & 33 & 78 & 0.13 \\
\hline 5 & 10 & 42 & 0.14 \\
\hline 8 & 33 & 62 & 0.14 \\
\hline 10 & 15 & 37 & 0.14 \\
\hline
\end{tabular}

\section{Discussion}

Simply using compost in horticulture has been shown to limit the growth of crops due to the high EC and excessive amount of certain ions that cause phytotoxicity (García-Gómez et al., 2002). Our results showed a general reduction in $\mathrm{Mn}, \mathrm{B}, \mathrm{Zn}, \mathrm{Cu}$, and Fe ion concentrations from the input (VCS) to the output (VCL). This reduction is beneficial because compost generally contains high concentrations of microelements that can be phytotoxic to plants. The $\mathrm{VC}$ technique was shown to be capable of reducing phytotoxic ions, such as Mn and B, in the leachate by more than 99\%; more importantly, the concentration of the inessential (Arnon and Stout, 1939) and even toxic $\mathrm{Na}+$ ion was reduced up to $47 \%$ (Table 1). However, the content of N in the VCL that was reduced by more than $97 \%$ may have been volatilized. This volatilization is one of the greatest problems in OA because $\mathrm{N}$ is consumed by the plant in large amounts. 
In contrast, the $\mathrm{pH}$ of the VCL was close to neutral, which did not correspond to the results reported by Tejada et al. (2008), who obtained a pH of 6 for VCL from cow manure. In our experiments, we obtained a $\mathrm{pH}$ of 7.27 for this CC. This result is important because with a lower $\mathrm{pH}$, less acid is needed to acidify the NS. The VCL output conditions were related to the raw materials that were used (substrates).

Soil salinity a severe problem which is not only reducing the agricultural potential, but also creating impacts on livelihood strategies of farmers (Haider and Hossain, 2013). Salts adversely modify the physical and chemical properties of the soil and cause decreased absorption of water and ion imbalances (McKenzie and Leshen, 1994). Although the concentrations of these ions in the VCLs in the present study were still above the accepted, ideal values (Steiner, 1984), reduced concentrations are very important because they reduce the toxic effects of these common supplements.

The VCL changes the physical properties of the soil. However, the values obtained herein for the different treatments were all different from that obtained for the control (T10), except for BD. A major reduction in HC was observed in the control, which reached $87 \%$; this reduction most likely reduced the infiltration of water into the ground and caused an increased accumulation of ions, such as $\mathrm{Na}+$. The greatest amount of $\mathrm{Na}+$ (562 ppm) and the highest EC (12.05 dS m $\left.{ }^{-1}\right)$ were obtained in the control at a soil depth of $30 \mathrm{~cm}$. The $\mathrm{HC}$ is important because it serves as an indicator of the hydrodynamics of the water and the movement of solutes in the ground. If the indicator falls below $0.5 \mathrm{~cm} \mathrm{~h}^{-1}$, as occurred in the T10 treatment, irrigation and drainage may become compromised (Saunders et al., 1978) and reduce crop yields. As reported previously, $\mathrm{OM}$ is related to $\mathrm{HC}$ because this material creates porous space due to the increased organic carbon (Tisdall and Oades, 1982). In our experiments, no direct correlation between these two factors was observed; the relationship depended on treatment. For example, treatments with $\mathrm{CC}$ (T7, T8, and T9) produced an average of $4.14 \% \mathrm{OM}$ and $0.95 \mathrm{~cm} \mathrm{~h}^{-1}$ $\mathrm{HC}$, whereas MSHW (T1, T2, and T3) yielded an average of $3.73 \% \mathrm{OM}$ and $2.25 \mathrm{~cm} \mathrm{~h}^{-1} \mathrm{HC}$ (Table 2). Another important finding was the high EC at a depth of $30 \mathrm{~cm}$; the highest EC was obtained for the control (12.05 $\left.\mathrm{dS} \mathrm{m}^{-1}\right)$, followed by MSHW, LCAW, and finally $\mathrm{CC}$, with an $\mathrm{EC}$ of $2.17 \mathrm{dS} \mathrm{m}^{-1}$. According to García-Gómez et al. (2002), applying compost alone can be detrimental to the crop because of its high EC. However, our results showed that the use of leachate from CC may be an alternative because it did not produce an increase in EC relative to the other treatments (Table 2). In addition, the use of VCL increased the CEC, which is consistent with the results reported by Weber et al. (2007). Furthermore, adding VCL as a supplement to the chemical solution decreased the amount of $\mathrm{Na}+$ in the soil. The excess sodium might have been adsorbed in the soil, or it could have leached into the soil. This decrease is based on the highest HC in soils treated with VCL compared with the control, which accumulated more $\mathrm{Na}+$ (Table 2).

There were no significant differences in the physiological variables (Table 3 ) between treatments, indicating that the VCL had no effect on the plants. Tomato fruit weight and physiological variables were not different between treatments $(p \leq 0.05)$. Increases in plant growth of corn, oats, snuff, soybeans, and other crops have been reported in treatments with VCL (Hayes and Wilson, 1997). Moreover, Arancon et al. (2006) found that feeding cucumber plants with $\mathrm{VC}$ increased the number of fruits. This finding does not correspond to the effects observed in our tomato plants treated with VCL because no significant difference $(\mathrm{P} \leq 0.05)$ was observed in plant growth or other physiological variables (Table 3), such as fruit 
yield $\left(\mathrm{kg} \mathrm{m}^{-2}\right)$. Nevertheless, a slight increase in the number of fruits per plant did occur in $\mathrm{T} 4, \mathrm{~T} 7$, and $\mathrm{T}$, which yielded 54 fruits compared with 50 fruits in the control (T10) (Table 3). This difference may have occurred, in part, as a result of the mode of application because previous authors mixed $\mathrm{VC}$ with the soil before planting.

In contrast, when mixing $\mathrm{VC}$ with the soil at ratios of 1:1 to 1:5, Gutiérrez-Miceli et al. (2007) observed no significant differences in tomato fruit yields 85 days after transplantation similar to those that were observed in our experiment with the VCL technique (Figure 1). It is clear that crop response to VCL or $\mathrm{VC}$ depends on the source or substrate and the shape, timing, and amount of application.

The sugar content of tomato fruit is an indicator of quality that is affected by plant genetics, nutrition type, and other factors (EC, pH, stress, etc.) (González et al., 2004). In general, tomatoes are considered to be of high quality only when the amount of sugar is higher than 4.5\%, (Nuez, 1995). Statistically, plants treated with VCL failed to generate a quantity of sugar greater than that of the control (T10). It is likely that the amount of VCL was not sufficient to generate the necessary biochemical changes in the fruit. For example, Gutiérrez-Miceli et al. (2007) obtained increased sugar levels in tomato fruit when they mixed VC with soil before transplantation, but others found no increases when applying VCL at doses of 5 to $15 \mathrm{t} \mathrm{ha}^{-1}$ (Azarmi et al., 2008). Thus, this indicator varies according to the conditions of the culture; we obtained more than $5 \%$ sugar in all of our treatments (Table 4). Another relevant characteristic of quality in fruit is $\mathrm{pH}$. Usually, a $\mathrm{pH}$ range from 4.17 to 4.59 is appropriate for fresh tomato fruit (Cantwell, 2006). Below a $\mathrm{pH}$ of 4.5 , fruit should be preserved due to the inhibition of microorganisms (mainly bacteria) (Ospina et al., 2008). Our results for $\mathrm{pH}$ and $\mathrm{EC}$ are similar to those reported by Gutiérrez-Miceli et al.
(2007). The $\mathrm{pH}$ obtained in all treatments was not different from that of the control, which indicates that VCL can be used as a nutrition supplement because it does not produce changes in fruit $\mathrm{pH}$.

Finally, the nutraceutical value of a fruit is as important as its volume and mass. Owing mainly to their antioxidant properties, lycopene, $\beta$-carotene, and phenolics are the most important secondary metabolites that indicate the quality of tomatoes both on the shelf and in processed products. In the present study, we conducted a preliminary evaluation of the influence of different treatments on the content of these compounds. To compare the yields of these markers between the different treatments, a constant volume of $50 \mathrm{ml}$ of tomato homogenate was used for extraction and chemical analysis. As shown in Table 5 , lycopene was the major compound synthesized in all of the treatments analyzed, whereas the yield of the only phenolic compound detected, rutin, did not depend on treatment. In contrast, the amount of $\beta$-carotene and lycopene varied considerably among treatments; they were most abundantly synthesized in treatments $\mathrm{T} 8$ and $\mathrm{T} 2$. The low quantity of $\beta$-carotene synthesized in treatment T5 compared with that of the control (T10) was also remarkable. Lycopene production depends on various factors, including the stage of ripening and, more importantly, the nutrients that are supplied. Although we did not find similar studies of treatments with leachates, at least one study has reported a similar production of lycopene in many cultivars under an organic production method (soil amended with organic poultry litter) (Perkins-Veazie et al., 2007). Our results showed up to $78 \mathrm{mg} \mathrm{kg}^{-1}$ of lycopene for T2 (Table 5).

\section{Conclusion}

In tomatoes, quality and fruit yield are two factors that must be taken into account during production. 
In this research, the results showed no difference in fruit yield between treatments, which indicates that VCL does not affect productivity. Standard sugar quality was obtained with no differences between treatments. Additionally, the yields of the fruit-quality indicators lycopene and $\beta$-carotene also improved in the treatments that were examined (T2, T5, and T8). These results indicate that irrigating with VCL does improve fruit quality without affecting yield. Furthermore, VCL can be a ground improvement technique because it increases the OM, CEC, and HC and reduces phytotoxic ions compared with compost or NS alone. This highly available supplement (CC) also helps prevent phytotoxicity and long-term soil saturation by ions. Therefore, we propose the use of leachates from $\mathrm{CC}$ at a concentration of $0.1 \mathrm{~L}_{\text {plant }}^{-1}$ and a frequency of 2 applications per week via an irrigation system as a supplement to NS in order to increase the lycopene and $\beta$-carotene content and maintain fruit yield in tomatoes.

\section{Acknowledgements}

We thank the Universidad Autónoma de Querétaro for sponsoring the experiment with a background resource record (FOFI), registration number FIN201209.

\section{References}

Arancon, N.Q., Clive, A.E., Lee, S., Byrne, R. 2006. Effects of humic acids from vermicomposts on plant growth. Eur. J. Soil Biol. 42, S65-S69.

Arnon, D.I., Stout, P.R. 1939. The essentiality of certain elements in minute quantity for plants with special reference to copper. Plant Physiol. 142, 371-375.

Azarmi, R., Sharifi, Z.P., Reza, S.M. 2008. Effect of vermicompost on growth, yield and nutrition status of tomato (lycopersicum esculentum). Pakisyan J. Biol. Sci. 11, 1797-1802.

Bennett, A.J., Bending, G.D., Chandler, D., Hilton, S., Mills, P. 2012. Meeting the demand for crop production: the challenge of yield decline in crops grown in short rotation. Biol. Rev. 87, 52-71.

Cantwell, M. 2006. Report to the California tomato commission tomato variety trials: Postharvest evaluation for 2005. UCCE Fresh market tomato statewide report. California, USA. pp: 9-13.

Connor, D.J. 2008. Organic agriculture cannot feed the world. Field Crop. Res. 106, 187-190.

de Ponti, T., Rijk, B., Ittersum, M.K.V. 2012. The crop yield gap between organic and conventional agriculture. Agr. Syst. 108, 1-9.

Frost, C.J., Mescher, M.C., Carlston, J.E., de Moraes, C.M. 2008. Plant defense priming against herbivores: getting ready for a different battle. Plant Physiol. 146, 818-824.

García-Gómez, A., Bernal, M.P., Roig, A. 2002. Ornamental plants growth in substrates using composts from agro industrial wastes. Bioresource Technol. 83, 81-87.

González, C.A., Salas, S.M.C., Urrestarazu, G.M. 2004. Producción y calidad en el cultivo de tomate cherry. In: G.M. Urrestarazu (ed). Tratado de cultivo sin suelo. Mundi-Prensa., Madrid, España, pp: 703-748.

Goswami, B., Kalita, M.C., Talukdar, S. 2001. Bioconversion of municipal solid waste through vermicomposting. Asian J. Microbiol. Biotechnol. Environ. Sci. 3, 205-207.

Gutiérrez-Miceli, F.A., Santiago-Borraz, J., Montes, J.A.M., Carlos, C.N., Abud-Archila, M., Oliva, M.A.L., Rincón-Rosales, R., Dendooven, L. 2007. Vermicompost as a soil supplement to improve growth, yield and fruit quality of tomato (Lycopersicum esculentum). Bioresource Technol. 98, 2781-2786. 
Haider, M.Z., Hossain, M.Z. 2013. Impact of salinity on livelihood strategies of farmers. J. Soil Sci. Plant Nutr. 13, 417-431.

Hayes, M.H.B., Wilson, W.S. 1997. Humic substances, peats and sludges; health and environmental aspects, first ed. Royal Society Chemistry, Cambridge.

Huber, M., Rembiałkowska, E., Srednicka, D., Bügel, S., van de Vijver, L.P.L. 2011. Organic food and impact on human health: Assessing the status quo and prospects of research. NJAS-Wagen. J. Life Sci. 58, 103-109.

Lazcano, C., Domínguez, J. 2010. Effects of vermicompost as a potting amendment of two comercially-grown ornamental plant species. Span. J. Agric. Res. 8, 1260-1270.

Márquez-Quiroz, C., López-Espinosa, S.T., SánchezChávez, E., García-Bañuelos, M.L., De la CruzLázaro, E., Reyes-Carrillo, J.L. 2014. Effect of vermicompost tea on yield and nitrate reductase enzyme activity in saladette tomato. J. Soil Sci. Plant Nutr. 14, 223-231.

McKenzie, B.D., Leshen, Y.A. 1994. Stress and stress coping in cultivated plants, first ed. Kluwer Academic Publisher, Netherlands.

Nuez, F. 1995. El cultivo del tomate, fisrt ed. Mundiprensa, Madrid, España.

Ospina, M.S.M., Cartagena, V.J.R. 2008. La atmósfera modificada: una alternativa para la conservación de los alimentos. Revista Lasallista de Investigación. 5, 112-123.

Perkins-Veazie, P., Roberts, W., Collins, J.K. 2007. Lycopene Content Among Organically Produced Tomatoes. J. Veg. Sci. 12, 93-106.
Resh, H.M. 2001. Cultivos hidroponicos, fifth ed. Mundi-Prensa. Madrid, España.

Saunders, L., Libardi, P., Reichardt, K. 1978. Condutividad e hidráulica da Terra Roxa Estruturada em condições de campo. R. Bras. Ci. Solo. 2, 164-7.

Steiner, A.A. 1984. The universal nutrient solution. pp. 633-650. In: Proceedings 6th International Congress on Soilles Culture. Wageningen. The Netherlands.

Story, E.N., Kopec, R.E., Schwartz, S.J., Harris, G.K. 2010. An Update on the Health Effects of Tomato Lycopene. Annu. Rev. Food Sci. 1, 187-210.

Tejada, M., Gonzalez, L., Hernandez, M. T., Garcia, C. 2008. Agricultural use of leachates obtained from two different vermicomposting processes. Bioresource Technol. 99, 6228-6232.

Tisdall, J.M., Oades, J.M. 1982. "Organic Matter and Water Stable Aggregate in Soils". Soil Sci. 33, 141-163.

Toora, R.K., Savagea, G.P., Lister, C.E. 2006. Seasonal variations in the antioxidant composition of greenhouse grown tomatoes. J. Food Comp. Anal. 19, 1-10.

Vitale, A.A., Bernatene, E.A., Pomilio, A.B. 2010. Carotenoides en quimioprevención: Licopeno. Acta Bioquím. Clín. L. 44, 195-238.

Weber, J., Karczewska, A., Drozd, J., Licznar, M., Jamroz, E., Kocowicz, A. 2007. Agricultural and ecological aspects of a sandy soil as affected by the application of municipal solid waste composts. Soil Biol. Biochem. 39, 1294-1302. 